\title{
Study of serum calcium levels in relation to ankle joint instability patients in Andhra Pradesh population
}

\author{
Sujit Ravi Teja ${ }^{1 *}$, Srinivasa Rao Puli²
}

\begin{abstract}
${ }^{1}$ Assistant Professor, Department of Orthopedics, Nimra Medical College, ibrahimpatnam, Andhra Pradesh-521456. INDIA. ${ }^{2}$ Assistant professor, Department of Orthopedics, Narayana Medical College, Nellore, Andhra Pradesh-524002. INDIA. Email: tejatpc@gmail.com
\end{abstract}

Abstract Background: Ankle joint contributes stability and formation of joint is multifunctional mainly mineral contents like Serum calcium which maintains density and prevents osteoporosis which leads to fractures and instability of joint. Method: 90 patients having instability of ankle joint compared with 90 controlled group. Age of both group was 23 to 45 years. Serum calcium, was studied and radiology of ankle joint was also studied, in both group and compared. Results: Mean value of AJI of Sr. calcium was 9.30 ( $\mathrm{SD} \pm 1.4)$ and controlled group was $12.1(\mathrm{SD} \pm 1.2) \mathrm{t}$ test was -14.4 and $\mathrm{p}<0.001$. In the radiological study osseous parameters were. In radial range of Ankle joint mean value of AJI group was $20.2(\mathrm{SD} \pm 2.3)$ and controlled group was $18.1(\mathrm{SD} \pm 1.8) \mathrm{t}$ test was $6.8 \mathrm{p}<0.001$. Sector of ankle joint in AJI group mean value was 79.2 $(\mathrm{SD} \pm 4.1)$ and controlled group was $87.3(\mathrm{SD} \pm 6.2) \mathrm{t}$ test was $-10.3 \mathrm{p}<0.00$. Height of Talus - Mean value in AJI group was $27.7(\mathrm{SD} \pm 1.9)$ and controlled group was $26.4(\mathrm{SD} \pm 3.0) \mathrm{t}$ test was $3.4 \mathrm{p}<0.005$. Conclusion: This pragmatic approach of Sr. Calcium levels and osseous parameters in radiology will be quite helpful to orthopedic surgeon, radiologist to treat such patients efficiently to avoid morbidity and mortality because Sr. calcium levels in bones forming joint is an global problem.

Key Words: AJI(Ankle Joint Instability), Sr. Calcium, Osseous parameters, Dietary Supplements, Hormones.

\section{*Address for Correspondence:}

Dr Ravi Teja MBBS MS, B N Sriram Hospitals, 41-1-74, Near Nallagate Centre, Krishna Lanka, Vijaywada-520013. (AP), INDIA.

Email: tejatpc@gmail.com

Received Date: $22 / 11 / 2019$ Revised Date: 14/01/2020 Accepted Date: 30/01/2020

DOI: https://doi.org/10.26611/1031532

This work is licensed under a Creative Commons Attribution-NonCommercial 4.0 International License. $(\boldsymbol{C c})$ EY-NC

\begin{tabular}{|l|l|}
\hline \multicolumn{2}{|c|}{ Access this article online } \\
\hline Quick Response Code: & Website: \\
\hline & www.medpulse.in \\
& \\
\hline
\end{tabular}

\section{INTRODUCTION}

Ankle joint instability is quite common phenomenon characterized by sports and recreational activities ${ }^{1}$. The anterior talofibular ${ }^{2}$ ligament is affected in $85 \%$ of ankle sprains. This type of injury represents sprain with ${ }^{3}$ a major component in sagittal plane. The average intake of calcium must be $700-900 \mathrm{mg} /$ day but clinical trials have of calcium supplements at doses of $1000 \mathrm{mg} /$ day. However Cardiovascular side effects ${ }^{4}$ and Kidney stones and acute Gastrointestinal symptoms ${ }^{(5)}$ were also reported. Hence it is mandatory to know the calcium levels especially those who are prone for fractures, joint instability. Otherwise it may cause secondary infections and may lead to morbidity and mortality.

\section{MATERIAL AND METHOD}

90 (Ninety Patients) who were regularly visiting Orthopedic Department, Nimra Medical College Hospital - Ibrahimpatnam (Andhra Pradesh) 521456 were studied.

- Inclusive Criteria: The patients aged between 23 to 45 having recurrent complaints of ankle sprain were selected for study.

- Exclusion Criteria: Patients having history of fracture of lower extremities having metal 
implant, having Thyroid problems. Patients already an thyroid or Calcium supplements

- Method: 90 patients selected were compared with 90 controlled group (volunteers). Study of serum calcium levels and radiological study of ankle joint in both groups were studied. The duration of study was December 2018 to December 2019
- Statistical analysis: The obtained results from both controlled group and affected group were compared with $\mathrm{t}$ test. The statistical analysis was done in SPSS software. The ratio of male and female were 1:2.

\section{OBSERVATION AND RESULTS}

Table 1: In the serum calcium mean value $1.30(\mathrm{SD} \pm 1.4)$ in Ankle Joint Instability(AJI) patients, $12.1(\mathrm{SD} \pm 1.2)$ mean value in controlled groups $t$ test value was -14.4 and $p$ value was highly significance $(p<0.001)$.

Table 2: Osseous parameters in radiological study - In the radial range of ankle joint $20.2 \mathrm{~mm}(\mathrm{SD} \pm 2.3)$ mean value in AJI group. $18.1 \mathrm{~mm}(\mathrm{SD} \pm 1.8)$ mean value in controlled group $\mathrm{t}$ test value was 6.8 and $\mathrm{p}$ value was highly significant $(\mathrm{p}<0.01)$. In the sector of Ankle joint study $79.2(\mathrm{SD} \pm 4.1)$ digits in AJI group and $87.3(\mathrm{SD} \pm 6.2) \mathrm{t}$ test value was -10.3 and $\mathrm{p}$ value was highly significant $(\mathrm{p}<0.01)$. Height of Talus $27.7(\mathrm{SD} \pm 1.9)$ mean value in AJI group, $26.4(\mathrm{SD} \pm 3.0)$ mean value in controlled group $t$ test value was 3.4 and $p$ value was significant $(\mathrm{p}<0.05)$.

Table 1: Study of Calcium levels in both groups

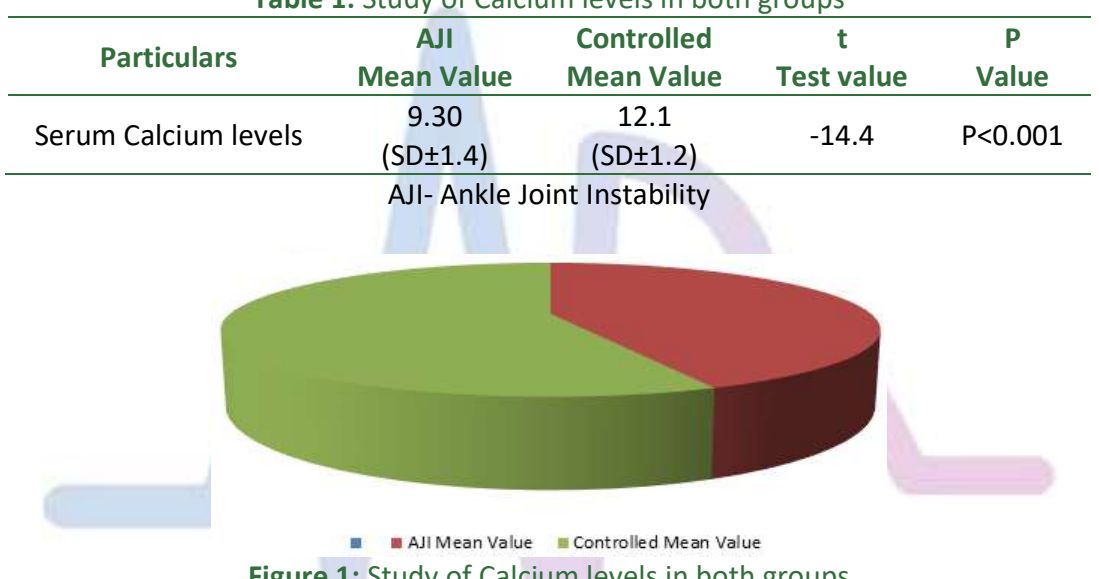

Figure 1: Study of Calcium levels in both groups

Table 2: Radiological study of ankle in both groups (Osseous Parameters)

\begin{tabular}{|c|c|c|c|c|}
\hline Particulars & $\begin{array}{c}\text { AJI } \\
\text { Mean Value }\end{array}$ & $\begin{array}{l}\text { Controlled } \\
\text { Mean Value }\end{array}$ & $\begin{array}{c}\mathbf{t} \\
\text { Test value }\end{array}$ & $\begin{array}{c}\mathbf{P} \\
\text { Value }\end{array}$ \\
\hline Radial range of ankle joint (mm) & $\begin{array}{c}20.2 \\
(S D \pm 2.3)\end{array}$ & $\begin{array}{c}18.1 \\
(S D \pm 1.8)\end{array}$ & 6.8 & $P<0.001$ \\
\hline Sector of ankle Joint (digits) & $\begin{array}{c}79.2 \\
(S D \pm 4.1)\end{array}$ & $\begin{array}{c}87.3 \\
(S D \pm 6.2)\end{array}$ & -10.3 & $\mathrm{P}<0.00$ \\
\hline Talus (mm) & $\begin{array}{c}27.7 \\
(S D \pm 1.9)\end{array}$ & $\begin{array}{c}26.4 \\
(S D \pm 3.0)\end{array}$ & 3.4 & $P<0.005$ \\
\hline
\end{tabular}

AJI- Ankle Joint Instability

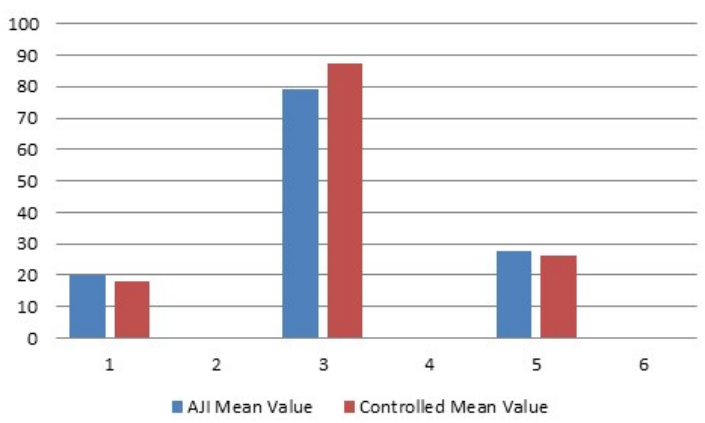

Figure 2: Radiological study of ankle in both groups (Osseous Parameters) 


\section{DISCUSSION}

In the present study of serum calcium levels in relation to Ankle joint instability patients in Andhra Pradesh population. The serum calcium levels mean value in AJI group was $9.30(\mathrm{SD} \pm 1.4)$ and $12.1(\mathrm{SD} \pm 1.2)$ in controlled group $t$ test value was -14.4 and $p$ value was highly significant $(\mathrm{p}<0.001)$. In the radiological study of osseous parameters - mean value in AJI group was $20.2(\mathrm{SD} \pm 2.3)$, $18.1 \mathrm{t}$ test value was 6.8 and $\mathrm{p}$ value was highly significant $(\mathrm{p}<0.001)$, mean value of sector of ankle joint in AJI group was $79.2(\mathrm{SD} \pm 4.1), 87.3(\mathrm{SD} \pm 6.2)$ in controlled group t value was -10.3 and $p$ value was highly significant $(p<0.01)$, mean value of height of Talus in AJI group was $27.7(\mathrm{SD} \pm 1.9), 26.4(\mathrm{SD} \pm 3.0)$ in controlled group t test value was 3.4 and $p$ value was significant $(p<0.05)$. These findings were more or less in agreement with previous studies $^{6,7,8}$ It is reported that especially nerve and muscle cells do not function properly unless they are bathed in the fluid whose calcium concentration does not fall below or above $11 \mathrm{mg}$ calcium per $100 \mathrm{~cm}^{3}$. If the concentration in the blood stream tends to fall then calcium is immediately and automatically withdrawn from exchangeable pool in the bones vice-versa. Parathhormone is a powerful hormone and if parathyroid hormone activity is abnormally high, skeleton melts away and its component are lost in urine. Normal growth of bone is dependent on anterior pituitary which stimulates cell division in the cartilaginous growth plates at the end of bones, however it is ineffective in the absence of sufficient thyroxin. The normalcy of content of calcium is influenced not only by age and sex but by economic status, individual total body weight and also possible by physical activity. ${ }^{9}$ Racial differences are taken into account but is very difficult to obtain reliable evidence on this point. Hence it may related to nutritional climatic and other factors ${ }^{10}$ Apart from calcium vitamin A also controls activity, distribution and co-ordination of the osteoblastic and osteoclastic activity to the sites where it is normally found and the reaction is often of very intense nature. Hence dietary supplement contains calcium (Vitamin D), Vitamin A, also play vital role in the joint stability. Risk of spraining of ankle joint depends on both intrinsic factors like hind foot alignment, laxity of ligaments, muscular co-ordination, neuro-muscular control and extrinsic factors involve shoe worn type and intensity of sports, warm-up etc. ${ }^{11}$ but rapid recovery depends on normalcy in bone mineralization and vascularity.

\section{SUMMARY AND CONCLUSION}

Ankle joint is one of the main weight bearing of body hence it needs lot of factors to stabilize its proper functioning. Calcium is proved to be one of the main mineral to maintain the density of the bones of ankle joint but this study further demands nutritional genetic hormonal, embryological, patho-physiological study because exact factors which determine the time of ossification are still obscure.

This research paper was approved by ethical committee of Nimra Medical College, Jupudi-521456. Andhra Pradesh

\section{REFERENCES}

1. Garrick J.G - The frequency of injury of mechanism of injury and epidemiology of ankle sprain. Am. J. Sports. Med. 1977, 5, 241-2

2. Baumhaver J.F, Alosa D.M - A prospective study of ankle injury risk factors. Am. J. Sports. Med. 1995, 23, 564-70

3. Leordini A, 'O' Connor J. J - Kinematics of human ankle complex in passive flexion a single degree of freedom system J. Biomechanics. 199 32, 111-18

4. Bolland M. J, Barber P. A - Vascular events in healthy older women receiving calcium supplementation: randomized controlled trial, BMJ. 2008, 336. 262-6

5. Lewis J.R, Zhy, K - Adverse events from calcium supplementation; relation to errors in myocardial infraction self-reporting in randomized controlled trials of calcium

6. Peaccok M-Calcium metabolism in health and diseases. Clin. J. Am. Soc. Neprol. (Suppl.) May, 2010, 23-30

7. Sunita. M. Agade, Pushpa. S. Rajan - Assessment of Serum Calcium levels in obesity in Indian population Medplus Int. J. of Biochem. 2017, 4(2), 36-39

8. Kim. Y - Food and nutrient consumption patterns of Korean adults by Socio-economic status. Korean J. Comm. Nutr. 2001, 6(2) 645-56

9. Flynn. A. - The role of dietary calcium in bone health, proc, Nutr. Soc. 1995, 55(2) 1-7

10. Anderson JJB, Roggenkamp K.S - Calcium intakes and femoral and lumbar bone density. J. Clin. Endocrine. Metabol, 2012 Vol.97(2) 4531-9

11. Armofrigg, Olaf MagerKurth - Chronic lateral ankle instability Br. J. Sports Med. 2007 vol.41(7), 420-42.

\section{Source of Support: None Declared} Conflict of Interest: None Declared

Policy for Articles with Open Access:

Authors who publish with MedPulse International Journal of Orthopedics, (Print ISSN: 2579-0889, Online) (ISSN: 2636-4638) agree to the following terms: Authors retain copyright and grant the journal right of first publication with the work simultaneously licensed under a Creative Commons Attribution License that allows others to share the work with an acknowledgement of the work's authorship and initial publication in this journal.

Authors are permitted and encouraged to post links to their work online (e.g., in institutional repositories or on their website) prior to and during the submission process, as it can lead to productive exchanges, as well as earlier and greater citation of published work. 